\title{
FENOMENA GINCU DALAM CERPEN INDONESIA BERTAJUK GINCU
}

\author{
Imayah $^{1}$, Imron Amrullah ${ }^{2}$ \\ ${ }^{1}$ Universitas Dr. Soetomo, imayah@unitomo.ac.id \\ ${ }^{2}$ Universitas Dr. Soetomo, imron.amrullah@unitomo.ac.id
}

\begin{abstract}
Abstrak: Penelitian ini bertujuan untuk mendeskripsikan pola pikir masyarakat terhadap penggunaan gincu oleh perempuan di tengah masyarakat Indonesia yang bermukim di pedesaan. Gejala ini dikaji berdasarkan ideologi pemikiran terhadap penggunaan gincu dan faktor yang memengaruhi proses pementukan ideologi tersebutn dengan menggunakan teori New Historicism. Hasil penelitian menun jukkan bahwa penggunaan gincu di tengah masyarakat Indonesia memiliki ragam dampak dan dampak yang diakibatkan adalah dampak negatif. Fenomena sosial seperti ini mengakibatkan perempuan Indonesia terkukung dengan pola pikir yang sempit terhadap penggunaan gincu, khususnya gincu yang berwarna cerah dan mencolok. Ada tiga penyebab yang menyebabkan perempuan yang mengguakan gincu mendapatkan persepsi negatif, yaitu: pandangan yang merendahkan perempuan, ketergantungan perempuan, dan kemiskinan serta rendahnya pendidikan perempuan. Teks fiksi yang mendukung maskulinitas dan mengabaikan feminisme menjadikan penelitian ini lebih menarik untuk dikaji. Dalam kehidupan sosial, tidak seharusnya perempuan terbelenggu dengan persepsi klasik yang semakin merugikan diri perempuan.
\end{abstract}

Istilah kunci: perempuan, gincu, pandangan

\begin{abstract}
Abstrak:This study aims to describe the mindset of the community towards the use of lipstick by women in the midst of Indonesian communities living in the countryside. This phenomenon is examined based on the ideology of thought towards the use of chips and factors that influence the process of ideological formation by using the theory of New Historicism. The results of the study show that the use of lipstick in the Indonesian community has a variety of impacts and the resulting impact is a negative impact. Social phenomena such as this result in Indonesian women being supported by a narrow mindset towards the use of bells, especially bright and striking colored lipstick. There are three causes that cause women to use gincu to get negative perceptions, namely: views that demean women, dependence on women, and poverty and the low education of women. Fictional texts that support masculinity and ignore feminism make this research more interesting to study. In social life, women should not be shackled by classical perceptions that are increasingly detrimental to women.
\end{abstract}

Key terms: women, lipstick, and outlook.

DOI: https://doi.org/10.33479/klausa.v3i01.155 


\section{PENDAHULUAN}

Perempuan di Indonesia seringkali mengalami berbagai gejolak dalam kehidupannya. Perempuan di Indonesia seringkali merasa dirinya terbelenggu dengan banyak aturan. Figur perempuan konon dan kini di Indonesia mengalami persegeseran. Namun tidak semuanya setuju dengan konsep kebebasan yang dianut oleh perempuan modern Indonesia masa kini. Itupun tidak lepas dari gunjingan yang mengatakan bahwa perempuan modern Indonesia adalah jenis perempuan yang tidak tahu ada istiadat yang melupakan dirinya dan tidak pantas dinilai oleh sekelompok orang untuk memiliki kebebasan seperti perempuan lainnya yang hidup dengan penuh kebebasan dan bisa menujukkan dirinya tanpa hidup di balik bayangbayang pria.

Perempuan dianggap lebih rendah dari laki-laki. Seakan-akan laki-laki adalah sosok istimewa yang mendapatkan tempat istimewa dengan segala hak bebas yang mereka miliki. Dalam masyarakat Indonesia yang masih menganut sistem patriarki, perempuan adalah sosok yang harus berada di bawah laki-laki, harus patuh, harus tunduk, dan sebagainya. Fenomena seperti ini menjadikan perempuan memiliki nilai terbatas, tidak bebas, dan cenderung terabaikan (Hikmat, 2002).

Salah satu bentuk dari pembelengguan perempuan di Indonesia adalah penggunan gincu. Gincu yang merupakan salah satu alat rias untuk mempercantik diri perempuan justru menjadi bomerang bagi perempuan. Konon, perempuan yang menggunakan gincu selalu dikonotasikan sebagai perempuan tidak baik atau bisa dikatakan sebagai pelacur atau penggoda. Konotasi tersebut belum hilang secara keseluruhan, dalam kehidupan sosial seperti di pedesaan, gincu, khususnya yang berwarna terang seperti merah dianggap sebagai sesuatu yang kurang pantas untuk digunakan perempuan. Hal ini menjadikan diri perempuan semakin terkukung.

Penelitian yang dilakukan Darni (2013) menunjukkan secara umum bahwa perempuan terbatas dalam aturan budaya, khususnya Jawa. Tidak hanya terbelunggu dalam nilai-nilai paradoks jawa, tetapi perempuan juga diperdangankan untuk meraih keuntungan. Perdagangan perempuan muncul dalam fiksi Jawa Modern. Peneltiian yang dilakukan oleh beliau mendeskripsikan praktik perdangangan wanita dalam fiksi Jawa Modern dengan menggunakan perspektif New Historiscsm. Penelitan ini lainnya dilakukan oleh Wismayanti (2010:63) menunjukkan adanya proses terjadinya perdangangan perempuan melalui perantara. Salah satunya adalah kerabat. Perdangan perempuan terjadi karena adanya unsur kerja sam antara pihak terkait dengan pihak terdekat yang diperdangangkan. Perempuan menjadi korban dalam kehidupan sosialnya.

Penelitian ini berbeda dengan peneliitan sebelumnya, penelitian ini fokus terhadap penggunan gincu sebagai bentuk pembelengguan diri perempuan di Indonesia dalam karya fiksi cerpen Indonesia yang berjudul Gincu ini Merah, Sayang! dari dua pengarang yang berbeda. Cerpen dengan judul yang sama lahir dari pengarang Eka Kurniawan dan Sanad. Keduanya memiliki persamaan mengankat gincu sebagai simbol pembelengguan perempuan di Indonesia. 
Menurut Darna (2007:136) sastra merupakan konteks sosial yang berlaku dalam tatanan masyarakat tertentu. Sastra lahir dari kondisi masyrakat yang melatarbelakangkinya. Setiap karya sastra yang lahir tidak lepas dari konteks sosio-budayanya. Karya sastra lahir dengan sistem yang penuh dengan sudut pandang. Bahkan dalam Swingewood (1972:19) diungkapkan bahwa karya sastra merupakan bentuk lain dari cerminan nilai dan norma yang berlaku di masyarakat. Di sisi lain, Wellek (2001:109) berpendapat bahwa karya sastra bukanlah karya yang mati, ia lahir dengan banyak nafas kehidupan.

Fenomena gincu dalam karya sastra yang bertajuk gincu di Indonesia akan dikaji dengan menggunakan pendekatan New Historicism. New Historisicm merupakan teori yang berfokus pada hal-hal yang terasingkan atau tidak mendapatkan perhatian khusus, seperti perempuan. Menurut Greenblatt (2000) New Historicism sebuah teks dapat dilihat hubungan konteks dengan teksnya yang meliputi: struktur sosial atau ideologi, kebebasan berpikir, pemahaman sosial, praktik sosial. Dalam penelitian ini, konteks yang dikaji adalah konteks yang membentuk pola pikir masyarakat terhadap gincu sehingga menjadikannya simbol pembelengguan bagi perempuan.

\section{METODE}

Penelitian ini merupakan penelirian deskriptif kualitatif dalam area sastra Indonesia. Penelitian ini bertujuan untuk mendeskripsikan pola pikir masyarakat terhadap penggunaan gincu oleh perempuan di tengah masyarakat Indonesia. Sumber data dalam penelitian ini adalah dua cerpen yang memiliki judul yang sama dengan konten yang berbeda. Kedua cerpen tersebut berjudul Gincu ini Merah Sayang!. kedua cerpen ini lahir dari dua pengarang yang berbeda, namun kedua pengarang memiliki persamaan yakni sama-sama berjenis kelamin pria. Cerpen pertama terbit pada tahun 08 September 2010 dan ditulis oleh Eka Kurniawan. Cerpen kedua terbit pada 15 April 2017 dan ditulis oleh Sanad, seorang mahasiswa.

Metode yang digunakan dalam penelitian ini memiliki dua sifar yakni deskriptif dan analitis. Kedua cerpen yang telah dipiih dibaca secara komprehensif, lalu data dideskriptifkan dan dianalisis. Data dijabarkan berdasarkan bukti yang tertera pada teks.

\section{HASIL DAN PEMBAHASAN}

Penelitian ini menghasilkan data bahwa gincu dalam dua karya fiksi yang memiliki persamaan judul memiliki perspektif yang bersifat konotatif sehingga menimbulkan efek pembelengguan erhadap perempuan sebagai pihak yang memgguakan gincu. Kedua cerpen sama-sama mengkritik fenomena sosial, khususnya terhadap makna gincu. Data lebih lengkapnya akan diuraikan pada pembahasan berikut.

\section{Pola Pikir Terhadap Gincu Dalam Cerpen “Gincu ini Merah, Sayang!” Karya Eka Kuniawan}

Cerpen pertama yang ditulis oleh sastrawan ternama, Eka Kurniawan mengisahkan seorang perempuan yang bernama Marni. Marni adalah seorang gadis lugu dari pedesaan yang tidak tahu apa-apa mengenai pekerjaan di bar ataupun menjual diri. Ia memutuskan bekerja sebagai ladies di sebuah bar. Awalnya ia hanya bertugas untuk menemani pengunjung makan atau minum. Lama-kelamaan pelanggan mulai menjamah tubuhnya hingga mengajak ia tidur. 
Marni yang hanya berpikir bagaimana ia bisa menghasilkan uang terpaksa mengorbankan keperawanannya setelah lima bulan ia bekerja sebagai ladies.

Tak sengaja, ia bertemu dengan seorang pelanggan yang akhirnya menjadi suaminya. Pria itu bernama Rohmat Nurjaman. Tiga tahun perkawinan mereka berjalan dengan kebahagiaan. Hingga akhirnya pada satu waktu, keduanya saling mencurigai apakah suaminya memiliki wanita lain atau sering ke tempat bar. Sedangkan sang suami berpikir apa benar istrinya berada di rumah sepanjang hari ataukah kembali bekerja di tempat bar dan bertemu pria lain.

Rohmat merasa ada sesuatu yang mengganjal. Hal itu tertuang dalam kutipan berikut:

Tiga tahun usia perkawinan mereka, namun Rohmat Nurjaman masih merasa sesuatu mengganjal dalam kehidupannya. Itu adalah gincu di bibir istrinya. Gincu yang sama sebagaimana ia pernah melihatnya di keremangan bar Beranda. Memang ketika mereka mengikrarkan pernikahan, keduanya telah berjanji untuk menjalani hidup sebagai suami dan istri, bukan pelayan bersama pelanggannya. Tetapi, Marni masih menggunakan Gincu yang sama dengan cara yang sama.

Kutipan di atas menggambarkan bahwa Gincu merupakan simbol pelabelan pada diri Marni yang tidak lain adalah seorang perempuan. Memang benar Marni memiliki masa lalu yang kurang baik, sama halnya dengan masa lalu Rohmat yang kurang baik. Namun dalam teks tersebut, Gincu dijadikan konteks sebagai pembelengguan diri Marni. Dapat terlihat jelas bahwa Rohmat selaku pria, ia menyatakan kebebasan berpikirnya untuk menilai istrinya.

\section{Pola Pikir Terhadap Gincu Dalam Cerpen “Gincu ini Merah, Sayang!” Karya Sanad}

Cerpen kedua yang ditulis oleh seorang mahasiswa dari sebuah perguruan tinggi di Indonesia. Pengarang tersebut menciptakan sebuah cerpen yang memiliki judul yang sama dengan kisah yang tidak jauh berbeda. Cerpen yang diciptakan oleh Sanad adalah cerpen yang menceritakan tentang sebuah wanita yang bernama Liyan yang amat mencintai suaminya bernama Komaruddin. Hingga suatu hari, Liyan harus rela melepaskan suaminya untuk bersanding dengan wanita lain yang bernama Deysi.

Komaruddin tiba-tiba lupa atau hilang ingatan, ia lupa akan istri dan anak-anaknya. Hal itu terjadi setelah ia pulang berburu. Setelah sekian lama, ingatan itu kembali terkenang melalui gincu yang dipakai oleh Liyan. Liyan adalah sosok wanita yang tidak suka menggunakan gincu. Pola pikir masyarakat terhadap gincu atau lipstik dapat dilihat dalam kutipan berikut ini:

Mereka menikah dan untuk pertama kalinya bibirnya kembal berwarna. Pertemuan mereka seperti ingatan akan kenangan yang bergambar namun tak berwarna, indah namun kelam, hingga tak pantas untuk dikenang. Kecuali gincu dibibir Liyan, Komaruddin tak bisa menyembunyikan getar dihatinya, seperti rasa ingin tahu yang tertutup tabir gelap, hingga ia akhirnya tanpa sengaja menyanjung Liyan kala itu.

"Kamu sekarang lebih cantik dengan gincu itu" tanya Komaruddin spontan.

"Ada apa?" jawabnya ketus

"Bukankah dulu kamu tak suka memakai gincu?" Komaruddin mengingat masa - masa penggugatan di kantor desa itu, ketika Liyan yang lusuh datang tanpa polesan sedikitpun diwajahnya. 
"Ya!"

"Kenapa?" tanya Komaruddin seperti seorang wartawan.

"Gincu ini merah dan itu hanya untuk suamiku, sayang!" balas Liyan seketika pergi, meninggalkan Komaruddin sendiri dengan kenangan-kenangan mereka yang ia sengaja jatuhkan bersama secarik kertas, seperti sebuah surat, yang kusut karena usia, dan juga remuk karena amarah, surat itu adalah surat dari Deysi untuk para pemburu.

Dalam kutipan di atas jelas tertuang bahwa gincu merupakan alat rias yang mempercantik seorang penggunanya. Gincu dalam konteks cerpen ini menguraikan secara implisit bahwa karena gincu, seorang suami meninggalkan istri dan anaknya dengan menggunakan taktik lupa ingatan agar bisa diterima oleh masyarakat.

Adanya tindakan pengkhianatan dikarenakan istrinya tidak menarik karena tidak bersolek atau tidak menggunakan gincu. Liyan yang dulunya tidak menggemari gincu sekarang ia berubah menjadikan gincu sebagai alat untuk mempercantik dirinya sekaligus membuktikkan kepada mantan suaminya Komaruddin bahwa ia adalah wanita yang cantik sama seperti Deisy, janda yang Komaruddin nikahi dengan alasan lupa ingatan.

Pola pikir masyarakat Indonesia terhadap gincu dalam kehidupan sehari-hari dan dalam kehidupan konteks teks sastra tidaklah jauhlah berbeda. Hal tersebut sesuai dengan pernyataan Arini (2006:88) bahwa tubuh merupakan salah satu bagian yang akan dinilai dengan segala aspek yang meliputinya. Gincu dipandang sebagai sesuatu yang menarik dan memikat dan penggunanya mendapatkan efek tertentu ketika menggunakan gincu. Dengan kata lain dapat dikatakan gincu merupakan lambang yang sifatnya konotatif negatif. Gincu dijerumuskan oleh pola pikir yang memandangnya sebagai sesuatu yang menggoda, lambang balas dendam, menggairahkan, dan dipakai oleh sosok yang bekerja sebagai pekerja seks komersial.

\section{SIMPULAN}

Melalui penelitian ini dapat ditarik kesimpulan bahwa karya sastra membuat realita menjadi konteks yang unik jika disajikan dalam konteks teks sastra. Hal itu terbukti dalam dua cerpen yang memiliki judul yang sama dan tema yang sama. Keduanya mengangkat topik gincu di dalamnya dengan latar pedesaan atau masyarakat yang masih memiliki pola pikir lugu terhadap sesuatu.

Sesuatu tersebut merupakan gincu. Pola pikir inilah yang terbawa hingga kini yang menjadikan gerak-gerik perempuan semakin terbatas. Gincu dalam kehidupan nyata dan kedua cerpen ini merupakan alat rias untuk memperindah bibir yang memiliki warna merah terang.

Warna gincu yang merah terang hingga kini dikonotasikan sebagai sesuatu yang kurang pas atau kurang cocok jika digunakan oleh perempuan yang bermukim di pedesaan. Kehidupan dan pola pikir tokoh wanita dalam kedua cerpen tersebut merupakan gambaran dari kehidupan perempuan desa yang belum bisa menunjukkan keeksitensiannya dengan bebas seperti perempuan yang hidup di perkotaan, khususnya kota-kota besar. This section is for the conclusion and suggestion for future researchers.

\section{DAFTAR PUSTAKA}

Aminuddin. 1996. "Metode Kualitatif dalam Penelitian Karya Sastra" dalam Aminuddin. Pengembangan Penelitian 26 LITERA, Volume 12, Nomor 1, April 2013. 
Arivia, Gadis. 2000. Jurnal Perempuan 15: Gender. Jakarta: Yayasan Jurnal Perempuan.

Barry, P. 2010. Pengantar Komprehensif Teori Sastra dan Budaya: Beginning Theory. Yogyakarta: Jalasutra.

Budiman, H. (2002). Lubang Hitam Kebudayaan. Kanisius.

Brannigan, John. 1999. "'Introduction: History, Power and Politics in Literary Artifact” in in Julian Wolfreys (ed.). Literary Theories. New York: New York University Press. Brata,

Budianta, M. (2006). Budaya, Sejarah, dan Pasar: New Historicism dalam Perkembangan Kritik Sastra." Jurnal Susastra, 3, 1-19.

Damono, Sapardi Djoko. (1979). Sosiologi Sastra: Sebuah Pengantar. Jakarta: Balai Bahasa.

Darni, D. (2013). “Fenomena Perdagangan Perempuan dalam Fiksi Jawa Modern.” LITERA, 12(1).

Endraswara, S. 2015. Etnologi Jawa: Penelitian, Perbandingan, dan Pemaknaan Budaya. Yogyakarta: Center for Academic Publishing Service.

Purwanto, B. (2001). "Historisme Baru dan Kesadaran Dekonstruktif: Kajian Kritis Terhadap Historiografi Indonesiasentris.” Humaniora, 13(1), 29-44.

Suparto. 2007. Astirin Mbalela. Yogyakarta: Narasi.

Susanti, R. (2010). Pendekatan New Historicism dalam Novel Glonggong Karya Junaedi Setiyono. Tesis tidak diterbitkan. Surabaya: Pascasarjana Universitas Negeri Surabaya.

Rachmah, Ida. (2004). Jurnal Perempuan 41: Seksualitas. Jakarta: Yayasan Jurnal Perempuan.

6 | Fenomena Gincu dalam Cerpen Indonesia Bertajuk Gincu 
ISSN: $2301-4822(p)$

DOI: 10.33479/klausa.v0301

\section{A 4 a Bahasa, dan Sastra}

\section{Editorial Team}

Editor-in-Chief

Journal Manager

Editors

Reviewers

Publisher

Address

Frequency
: Dr. Daniel Ginting

: Wawan Eko Yulianto, Ph.D.

: $\quad$ Prof. Dr. Patrisius I. Djiwandono

Lilis Lestari Wilujeng, M.Hum.

: $\quad$ F.X Dono Sunardi, M.A.

Dhatu Sitaresmi, MTCSOL.

Anggrah Diah Arlinda, MTCSOL.

Prof. E Sadtono, Ph.D.

Yohanna Nirmalasari, S.Pd., M.Pd.

Prof. A. Effendi Kadarisman, Ph.D.

Sisilia Halim, Ph.D.

Dr. Mundi Rahayu

Dr. Ross Wood

Dr. Leticia Araceli Salas Serrano

: Faculty of Language and Arts

Universitsas Ma Chung

: The Faculty of Language and Arts

Ma Chung University

Villa Puncak Tidar N-01 (65151)

Malang, East Java, Indonesia

Email: jurnal.klausa@machung.ac.id

: $\quad$ Twice a year 